SIX RESTORATION AND FRENCH NEOCLASSIC PLAYS 
Also edited by David Thomas and published by Macmillan

FOUR GEORGIAN AND

PRE-REVOLUTIONARY PLAYS

THE RIVALS, SHE STOOPS TO CONQUER,

THE MARRIAGE OF FIGARO, EMILIA GALOTTI 


\title{
Six Restoration and French Neoclassic Plays
}

\author{
Phedra \\ The Miser \\ Tartuffe \\ All for Love \\ The Country Wife \\ Love for Love
}

Introduced and Edited by

DAVID THOMAS

Professor of Theatre Studies, University of Warwick 
Introductions, editorial matter and selection @ D David Thomas 1998

All rights reserved. No reproduction, copy or transmission of this publication may be made without written permission.

No paragraph of this publication may be reproduced, copied or transmitted save with written permission or in accordance with the provisions of the Copyright, Designs and Patents Act 1988, or under the terms of any licence permitting limited copying issued by the Copyright Licensing Agency, 90 Tottenham Court Road, London W1P 9HE.

Any person who does any unauthorised act in relation to this publication may be liable to criminal prosecution and civil claims for damages.

The author has asserted his rights to be identified as the author of this work in accordance with the Copyright, Designs and Patents Act 1988.

First published 1998 by

MACMILLAN PRESS LTD

Houndmills, Basingstoke, Hampshire RG21 6XS

and London

Companies and representatives

throughout the world

ISBN 978-0-333-63675-6

ISBN 978-1-349-26945-7 (eBook)

DOI 10.1007/978-1-349-26945-7

A catalogue record for this book is available

from the British Library.

This book is printed on paper suitable for recycling and made from fully managed and sustained forest sources.

$\begin{array}{llllllllll}10 & 9 & 8 & 7 & 6 & 5 & 4 & 3 & 2 & 1\end{array}$

$\begin{array}{llllllllll}07 & 06 & 05 & 04 & 03 & 02 & 01 & 00 & 99 & 98\end{array}$

Typeset by Forewords, Oxford/Longworth Editorial Services Longworth, Oxfordshire.

Published in the United States of America 1998 by

ST. MARTIN'S PRESS, INC.,

Scholarly and Reference Division,

175 Fifth Avenue, New York, N.Y. 10010

ISBN 978-0-312-21400-5 cloth

ISBN 978-0-312-21401-2 paperback 


\section{Contents}

List of Illustrations

vi

Acknowledgements

vii

General Introduction

viii

France: The Cultural and Political Context

England: The Cultural and Political Context

viii

The Plays

$\mathrm{x}$

Playhouses in Paris and London in the Seventeenth Century

xii

Note on the Texts

$x v i$

Notes to the Introduction

xix

xxii

Phedra

Introduction

Text

The Miser

Introduction

Text

Tartuffe

Introduction

Text

All for Love

Introduction

Text

The Country Wife

Introduction

Text

Love for Love

Introduction

Text

Bibliography 


\section{List of Illustrations}

A scene from Le Tartuffe, drawn by J. M. Moreau, reproduced 128 from CEuvres de Molière (Paris, 1773)

Mrs Hartley as Cleopatra in All for Love, reproduced from

Bell's British Theatre, vol. 5 (London: John Bell, 1780)

Mr Wilson and Mrs Mattocks in the characters of Ben and 374 Miss Prue in Love for Love, reproduced from The New English Theatre (London: T. Lowndes \& Partners, 1776)

(Reproduced from the author's collection) 


\section{Acknowledgements}

In preparing this volume, I have had invaluable help from staff in the Reading Room of the British Library, and the University Libraries of Warwick and Bristol. I should also like to record my thanks to the University of Warwick for generous research leave and for making a grant to cover some of the costs involved in preparing this volume for publication. My thanks are also due to Dr Edward Forman of the Department of French, University of Bristol, for his helpful comments on my introductions to the plays of Molière and Racine. As ever, the staff at Macmillan Press have given their unstinting help and support in bringing this volume to publication. I am particularly indebted to my commissioning editors, Margaret Bartley and Belinda Holdsworth. I would also like to thank Valery Rose and Nick Allen for their attention to detail in copy-editing and setting the text. On a more personal note, I would like to thank Coucou Lyall for her warm and untiring support. 


\section{General Introduction}

\section{France: The Cultural and Political Context}

During the course of the seventeenth century, both France and England experienced far-reaching cultural and political upheavals, which had a profound effect on the drama and theatre of the period. In France, there was a sustained attempt to impose cultural unity and political centralisation on a nation that had been riven by religious and regional conflicts. The instigator of this drive for centralisation was Cardinal Richelieu, chief counsellor to the weak and ineffective King Louis XIII and his Queen, Anne of Austria. During the 1620s Richelieu successfully broke the power of the Protestant free cities in France, commencing with the siege of $\mathrm{La}$ Rochelle in 1628. Simultaneously he began to pick off those feudal nobles who had sided with the Protestants. In 1634 he founded the Académie francaise in order to impose the same degree of centralised control over language and literature as he was gradually imposing on society. Richelieu was arguably the first great statesman to recognise the importance of language as a crucial building block in the creation of cultural and political identity.

In 1637, a public squabble over the merits of Corneille's play Le Cid gave Richelieu an ideal opportunity to set out guidelines for playwriting. Corneille's play had enjoyed enormous public success, but was attacked by fellow writers, notably Scudéry. Richelieu invited the newly founded Académie francaise to examine the play and pronounce its judgement on it. He himself greatly disliked the work, which seemed to him to glorify the values of those freebooting, feudal noblemen whom he had for years been fighting. He therefore made sure that the evaluation of the play, written for the Académie by Jean Chapelain, would amount to a powerful condemnation of the piece. Les Sentiments de l'Académie francaise sur le Cid, published in 1637, amounted to a swingeing official critique 
of the whole play, which in turn implied a set of principles to be followed by authors in future. Possibly the key statement in this document is the assertion that, 'not all truths are good for the theatre'; 1 authors should therefore be prepared to alter even the facts of history rather than risk offending the universal and ideal values implied in propriety, decorum and verisimilitude. Plays should offer a pattern of moral instruction rather than reflect the imperfections of history and everyday life.

Richelieu was only partially successful in building a centralised state in France: in politics, as in literature, he met with continuous opposition. Even after his death, there was another brief period of feudal civil war during the 1650s (known as la Fronde), when disaffected noblemen made a last attempt to preserve their feudal privileges. The latter half of the seventeenth century in France saw the final creation of the absolutist state by Louis XIV who came to the throne in 1661. Louis was a remarkable man who achieved what Richelieu had only dreamt of. He tamed the nobility and imposed the strictest of limitations on contemporary literature, and all of this was achieved with single-minded determination. Versailles was the key to it all. By extending his father's hunting chateau at Versailles, miles from the capital, and by transferring the centre of government to his court there, Louis ensured that he became the centre of attention and that any nobleman who wanted to further his own interests would be in constant attendance. At Versailles, Louis used ritual, dress codes and conventions as primary weapons in controlling people and their ideas. The expensive rituals and dress codes helped to impoverish the nobility and made them totally dependent on the king, ${ }^{2}$ and the generous grants and subventions given to artists and writers ensured that they became the king's creatures. In this context, neoclassicism became an essential tool for ensuring unquestioning adherence to literary principles favoured by the state.

The battle over Le Cid had established the undisputed importance of neoclassic precepts for contemporary authors. By the age of Louis $X I V$, the whole canon of neoclassic expectations could be taken for granted. These included the pursuit of an ideal truth; a cautious approach to history; characters whose behaviour would always be socially and philosophically appropriate and acceptable; tightly structured plots obeying the unities of time, place and action; stylised language used within an overall didactic framework. The problem confronting the critics and authors of Louis XIV's day was to determine how best to operate within the known limitations 
imposed by accepted laws and conventions. How much imaginative freedom was left to an author working within the neoclassic tradition? How far could an author safely permit himself to go in pursuit of a particular theme or approach to character? These issues were brought to a head in the lives of both Racine and Molière.

\section{England: The Cultural and Political Context}

In contrast to France, England at the beginning of the seventeenth century was seemingly a prosperous united kingdom. The various regional, religious and feudal conflicts which had almost destroyed the fabric of ordered society in France were unknown in Elizabethan and Jacobean England. But the apparent stability of English society was misleading. Both James I and his son Charles I, who came to the throne in 1628, were obsessed by the notion of divinely sanctioned kingship. Their single-minded pursuit of absolute authority inevitably brought them into conflict with the Puritan merchant classes and minor gentry who were equally determined in their commitment to parliamentary rule. While the king enjoyed the trappings of power, it was the merchant classes who controlled the real wealth of the nation. During the reign of Charles I, neither side was willing to compromise; civil discord was therefore inevitable.

The mistake made by Charles I was to believe his own rhetoric rather than acknowledge the realities of political life which confronted him. Architects, painters and playwrights were all enlisted to illustrate the mythology of divinely approved kingship to which he was so fervently committed. The focus for this activity was the magnificent Banqueting House in Whitehall, constructed by Inigo Jones for James I in the early 1620s. Jones's imposing design, based on the example of Palladio in Renaissance Italy, was London's first neoclassic state building. Towering above the rambling Tudor Palace of Whitehall, it was a self-confident assertion of James I's vision of himself as a powerful Renaissance ruler. His son Charles I embellished this vision by commissioning Rubens to decorate the Banqueting House in 1635 with a number of splendid ceiling panels depicting The Union of England and Scotland, The Benefits of the Government of James I and finally The Apotheosis of James I. Throughout the 1630 s sumptuous masques were performed in the Banqueting House (or in a masquing house constructed alongside it) which showed Charles I as the true inheritor of his father's wise vision of kingship. Even in 1640, at the very point in time when the country 
was sliding inexorably into Civil War, Charles I took part in a masque entitled Salmacida Spolia, which was designed to show him as a wise and just ruler, the bringer of peace and concord to a troubled realm. Reality and mythology were now diametrically opposed.

By 1642, instead of bringing peace and concord, Charles I found himself raising his battle standards to fight a full-scale civil war against his own subjects. After six weary years of conflict, the royalist forces were decisively beaten by Oliver Cromwell's New Model Army at Preston in 1648. The king found himself arraigned before a Rump Parliament purged of all dissenting voices; he was tried, found guilty and sentenced to death. In a deliberate attempt to destroy the myth of divinely sanctioned kingship that Charles I had so carefully constructed, Cromwell ordered that the king should be led to his execution in Whitehall through the Banqueting House which the Stuart monarchs had built, decorated and used to celebrate their myth.

During the reign of Charles I, the king's personal enthusiasm for all the arts and his profound distaste for Puritan views guaranteed that writers and actors could pursue their craft relatively unhindered. As a result, London in the 1630s was a thriving cultural centre with a significant number of large outdoor and smaller indoor playhouses, catering for a wide variety of tastes. In Puritan eyes, however, playhouses were not only intrinsically sinful, they were also viewed as politically undesirable disseminators of royalist propaganda. It was therefore not surprising that, after the outbreak of Civil War in 1642, Parliament enacted legislation to suppress the theatres, effectively silencing playwrights and actors for the next two decades.

Cromwell's death in 1658 brought a rapid deterioration in ordered government. This prompted General Monck to march on London from Scotland, setting in train a process that led to Parliament inviting Charles II to return from exile. Restored to the throne in 1660, Charles II had the supremely difficult task of reconciling the hierarchical view of kingship and society he had inherited from his father with the more egalitarian, Puritan sensibilities of a significant section of the population. He trod a cautious path through this political minefield. Although the process began with a deliberate symbolic reversal of his father's last journey - both Houses of Parliament were summoned to greet him at the Banqueting House on 29 May 1660 and testify their 'Vows of Affection and Fidelity 
to the utmost Degree of Loyalty ${ }^{3}$ - Charles II avoided giving unnecessary offence to the Puritan classes who had so effectively rebelled against his late father's authority.

Following the Restoration, Puritan objections to playwrights and playhouses were no longer an immediate threat. One of Charles II's earliest pieces of legislation was the granting of a warrant in August 1660 to Sir William Davenant and Thomas Killigrew to set up two theatre companies in London. However, the stated excuse for granting this warrant, namely the king's desire to suppress any plays containing 'much matter of profanation and scurrility', ${ }^{4}$ was clearly designed to placate Puritan sensibilities. The real problem confronting a new generation of playwrights at the Restoration was knowing where to begin. The links with the traditions of the Elizabethan and Jacobean age had been broken by the civil war, although the plays of this period were still a powerful influence to be reckoned with. On the other hand, a new and equally powerful literary tradition, based on strict neoclassic ideas, had been developed in France. Which way should writers turn? Dryden, Wycherley and Congreve found their own individual responses to this dilemma.

\section{The Plays}

The plays chosen for inclusion in this volume represent some of the finest achievements of French and English theatre in the late seventeenth century. All of them explore the theme of sex, marriage and society. In each case, the treatment of the theme reflects the profoundly divergent values and beliefs underpinning French and English society in the late seventeenth century. In the France of Louis XIV, the iron grip of the king over political life was matched by the steely grip of the Catholic church over the spiritual and moral welfare of the nation. In contrast, England in the reign of Charles II, and even more during the brief reign of James II, was a nation divided both spiritually and politically. This meant that in France there were generally accepted moral and political codes of behaviour which dramatists ignored at their peril. In England, however, there was a spiritual and intellectual vacuum at the Restoration which gave dramatists unprecedented scope to challenge and question accepted patterns of behaviour.

Both Phèdre/Phedra and All for Love explore the consequences of an adulterous passion, but the treatment could not be more divergent. 
The very notion of unlawful passion, as experienced by Phèdre, is treated with utter revulsion by Racine. Phèdre's destructive and irrational passion, over which she has no control at all, threatens and ultimately overwhelms the ordered fabric of society. As Racine shows it in his play, marriage is a far from perfect institution but it brings order and stability to a world that might otherwise fragment. Adulterous passion leads to chaos, disorder, poison and death. In complete contrast, the adulterous love affair of Antony and Cleopatra in Dryden's All for Love is treated with sympathetic warmth. Although the adulterous passion of Antony and Cleopatra threatens the ordered stability of the contemporary world, the subtitle of Dryden's play, 'the World well lost', makes it clear that the values of the world are so flawed that they are not worth preserving. The love of Antony and Cleopatra is therefore shown as something pure and innocent, rather than something disordered and discreditable. A hostile world inevitably destroys their love, but the whole thrust of the play suggests that it is the world that is at fault and not their love.

In his comedies, Molière tends to satirise the conduct of characters who threaten or flout a generally accepted set of moral values. Tartuffe can be shown to be a dangerous impostor because he uses the cloak of religious hypocrisy to disguise his real, and far more earthy intentions. His real aims are distinctly menacing, namely to procure Orgon's daughter as a subservient wife and to acquire Orgon's wife as an equally submissive mistress. Masquerading as a saint, his aggressive behaviour is a very real threat to the normal ordered stability of family life. Orgon is satirised for too readily believing Tartuffe's lies. His completely absurd infatuation with Tartuffe's saintliness puts his own marriage at risk and threatens the future happiness of his children. For Molière, marriage and family life are tangible realities that can be put at risk through irrational folly. In complete contrast, Wycherley shows characters struggling to make sense of a world where there are no meaningful norms against which conduct can be measured. Contemporary society is shown by Wycherley to be so completely corrupt and hypocritical that Horner, who is at least refreshingly honest, seems by comparison with the others to be an attractive character. Like Tartuffe, he is an impostor who uses a strategy of deliberate deception to obtain the sexual gratification he desires, but in contrast to Tartuffe there is no suggestion of any hidden threat or menace in his behaviour. His various sexual partners are more than willing accomplices. Marriage 
has become an empty shell, a form of financially based entrapment, which offers its female victims no real social or sexual satisfaction. The only thing that prevents open rebellion by the bored and frustrated wives of contemporary London is the threat of scandal and the consequent loss of reputation. Horner is astute enough to realise this and offers his partners a way of preserving their 'reputation' intact, while together they gleefully subvert the normal laws and conventions governing patriarchal society.

It is not until Congreve writes his comedies in the reign of William and Mary that English society begins to acquire a generally shared set of social and political values. This enables Congreve to satirise the behaviour of characters who deviate from this newly accepted norm. Because of this, his comedies are closer in approach to those of Molière than is the case with earlier Restoration comedies, but the tone is still significantly different. In $L^{\prime}$ Avare Molière never questions Harpagon's right to exercise his authority as a father; what is questioned is the way he exercises that authority. His attempt to marry his son's beloved is satirised as a clear abuse of his authority. $\mathrm{He}$ is a foolish older man attempting to purchase a young bride who is already in love with his son. Instead of contemplating a deed of such crass folly, his clear duty as a father is to think of his son's future happiness. Harpagon is satirised because he is too selfabsorbed to think of anyone else at all. This makes him useless as a father, in contrast to Anselme. In Congreve's Love for Love, the political base has shifted from an acceptance of absolute authority to the acknowledgement of consent as the underlying basis of personal and political life. This means that Sir Sampson Legend's attempt to marry his son's beloved is not satirised as an abuse of his rightful authority as a father. What is satirised is his attempt to exercise absolute authority in the first place. As Congreve sees it, Sir Sampson has no right to demand total obedience from his son without offering real affection in return. Having tried to bring Valentine to heel by crushing him financially, Sir Sampson now attempts to humiliate his son sexually by marrying Angelica. Such behaviour is not simply foolish, it is pernicious. That is why he is dismissed with such cutting disdain at the end of the play. All relationships - personal, sexual and political - must be based on consent. That will be the foundation of Valentine's and Angelica's marriage, which ensures that it will be a genuine relationship and not just an empty shell.

Given the firm political and moral constraints facing them, there 
is an understandably greater caution in the approach of both Racine and Molière than in the work of their English contemporaries. Even so, both Racine and Molière managed to offend powerful factions in society. Racine offended many at court with his ruthless, amoral dissection of human passion, while Molière offended many in the church with his frank exposure of religious hypocrisy in contemporary society. The challenge facing English writers was quite different: it was to gain the attention and esteem of a sceptical and demanding audience who wished to see their own views and behaviour patterns reflected on stage. Playwrights were expected to probe the paradoxes and uncertainties of contemporary life with honesty and wit, but without boring or alienating a fickle and capricious audience. The taste of the town demanded a greater honesty and earthy realism than would have been tolerated in France. But the taste of contemporary audiences could also change rapidly, as Congreve discovered to his cost. The constraints facing English playwrights were therefore more overtly commercial than was the case in France.

By the end of the seventeenth century, Louis XIV's grip on political and cultural life in France was undiminished. The theatre was under firm royal control, with the remains of Molière's troupe instructed to amalgamate with the actors from the Hôtel de Bourgogne to form La Comédie-Francaise in 1680. One further troupe of players was tolerated, the Italian players, who had previously shared the Palais-Royal with Molière. However, they were unceremoniously ordered out of France in 1697 for satirising the King's mistress, Mme de Maintenon, in a satirical piece called $L a$ fausse prude. They were not allowed to return for the remainder of Louis XIV's reign. ${ }^{5}$ In England, the situation was very different. The Lord Chamberlain exercised direct control over the theatre, but there were frequent challenges to his authority. There was also a far stronger commercial base for the theatre in London than was the case in Paris. By the turn of the century, there were two rival theatre companies operating in London. Soon the pressure would increase for a proliferation in theatre companies to cater for a growth in audiences with widely divergent tastes. Two divergent theatre traditions had been established by 1700 in France and England - the one state controlled, the other commercially based. Both traditions were to come under pressure in the eighteenth century, but that is another story for another volume. 


\section{Playhouses in Paris and London in the Seventeenth Century}

At the beginning of the seventeenth century there was only one playhouse in Paris, the Hôtel de Bourgogne, built in 1548 by the Confrérerie de la Passion. The confraternity was a loose association of merchants, tradesmen and representatives of the professions, formed in the late fourteenth century with the express intention of presenting Passion plays to audiences in Paris. Ironically, in the very decade when they acquired their theatre, they were forbidden to perform religious plays. ${ }^{6}$ Instead they were given permission to perform secular plays or to rent out their playhouse to visiting troupes. Designed to suit the demands of medieval theatre practice, the Hôtel de Bourgogne had a large standing pit, a single tier of raised side boxes, a raked amphitheatre at one end of the building and, at the other end, a cramped raised stage approximately at head height of those standing in the pit. There was no provision for changeable scenery; any locations were indicated by static mansions. ${ }^{7}$ The function of this interior layout was to bring a large number of standing spectators into immediate contact with players performing increasingly earthy and robust farces, while allowing a smaller number of well-to-do spectators to remain aloof from the rest.

A similar interior layout was copied from the Hôtel de Bourgogne when Paris acquired its second indoor playhouse, the Theatre du Marais in 1634. Like the Hôtel de Bourgogne, it was converted from one of the many real tennis courts in the city, this time in the fashionable Marais district. Once again a standing pit was flanked by raised side boxes, although here there was also a single tier of front boxes with a stepped amphitheatre above. The stage was at head height of those standing in the pit, and initially had no provision for changeable scenery. This was the theatre in which Corneille's tragedies and tragi-comedies were performed throughout the 1630s. In the 1660s, Racine's tragedies were performed at the Hôtel de Bourgogne, which had been significantly refurbished in 1647 , but which still retained its original configuration of raised stage, standing pit and tiers of raised boxes. ${ }^{8}$ It could be argued that this auditorium lay-out, inspired by the earthy traditions of medieval theatre, was no longer appropriate for the subtlety and complexity of French neoclassic theatre with its appeal to a more sophisticated audience. Nevertheless, it continued to inspire French 
playhouse design throughout the seventeenth century. For instance, the Théâtre du Palais-Royal, refurbished for use by Molière, still had a standing pit flanked by raised side and front boxes (in a flattened V-shape, rather than the rectangular shape of the Marais). However, the amphitheatre which, in the Hôtel de Bourgogne, had been a tiered structure on the far end wall opposite the stage, now began to encroach into the standing pit and took on the appearance of a seated pit area immediately behind the standing pit. ${ }^{9}$ Essentially this same lay-out was utilised by d'Orbey when he designed the new Comédie-Francaise in $1689 .{ }^{10}$

In complete contrast to Paris, London had a widespread and thriving theatre culture prior to the Civil War. By the 1630s there were some ten so-called public and private playhouses in the capital. The public playhouses, such as the Globe, the Swan, the Hope, the Fortune, and the Red Bull, were substantial structures (most were circular or octagonal), with a large, open-air pit surrounded by tiers of seating in covered galleries for the well-to-do. The raised stages in these structures were covered by a canopied roof, supported in most buildings by pillars; there was no provision for changeable scenery. Many of these buildings were used for animal-baiting as well as theatrical performances, which suggests that the stages may have been easy to dismantle. The basic layout of these playhouses grew organically from the robust traditions of medieval theatre practice. ${ }^{11}$ The private playhouses, such as the Cockpit (or Phoenix) in Drury Lane, Salisbury Court and the Blackfriars, were smaller, indoor structures, some of which were converted from existing buildings. Higher ticket prices were charged than in the public playhouses, which in turn meant that seating was provided in both pit and galleries for a more discerning audience. A section and ground-plan by Inigo Jones for a roofed private playhouse, which may have been used for the Phoenix or the Salisbury Court, shows an intimate theatre structure with a curved auditorium divided into a seated pit and galleries, and a small stage backed by a permanent scenæ frons of neoclassic design. ${ }^{12}$

During the civil war, London's playhouses were closed by Parliament and many were subsequently destroyed by Cromwell's soldiers. At the Restoration, Charles II granted only two patents to Thomas Killigrew and Sir William Davenant to set up theatre companies and provide suitable buildings for their companies. For the first few months they made use of the two remaining roofed playhouses in London, the Phoenix in Drury Lane and the Salisbury 
Court Theatre. But both were too small for the audience capacity that would be needed for commercially profitable theatrical enterprises. Some other model had to be found for the indoor playhouses needed by both companies.

Killigrew and Davenant had stayed in Paris at various points during the troubled times of the 1640s and 1650s. While there, they had the opportunity of seeing the French solution to the problem of creating commercially viable indoor playhouses by converting real tennis courts into theatres. Both of them were sufficiently impressed by the Parisian tennis court theatre, the Théâtre du Marais, to realise that converting real tennis courts in London could provide an immediate and practical solution to their needs. Even though they were probably rather less impressed by the internal layout of the theatre, notably the standing pit, both of them resolved to adapt real tennis courts for their respective theatre companies in London. Killigrew opened his conversion of Gibbons's Tennis Court in Vere Street, Clare Market in November 1660. Although he had intended to make provision for changeable scenery, there is no evidence that he did so. Davenant took greater pains over his conversion and finally opened his scenic theatre at Lisle's Tennis Court in Lincoln's Inn Fields in June 1661.

Brief contemporary descriptions suggest that the auditorium of the playhouse in Lincoln's Inn Fields was divided into a seated pit, flanked by two tiers of side and front boxes. Lighting was provided by hooped chandeliers over the stage area, a trough of oil lamps to serve as footlights at the front of the stage, and wall-mounted sconces in the auditorium. The stage area was divided into two sections; a downstage acting area in the auditorium, approached through one or possibly even two pairs of stage or proscenium doors with balconies above them; and an upstage scenic area, separated from the acting area by the proscenium arch. The advantage of intimate actor-audience contact was preserved by extending the side boxes up to the edge of the non-scenic stage area. Finally, the practical doors that were an essential feature of Elizabethan and Jacobean theatres, mounted in the scenæ frons of the non-scenic stage, were pushed to the side in order to open up the stage for scenic display. The scenic stage, located beyond the proscenium arch, was essentially a background for the actors, not a surround. This meant that stage settings could be illustrative rather than detailed. The side wings, for instance, normally remained unchanged throughout the performance. Important changes of 
location were indicated by painted shutters drawn across the stage to meet in the centre.

In arriving at this pragmatic solution, Davenant established the basic shape and structure of most theatres built in London and the provinces for the next 150 years. In doing so, he achieved a typical English compromise between the traditions of an Elizabethan actors' theatre and the demands of the scenic stage. His theatre in Lincoln's Inn Fields seems designed to break down the barriers between stage and auditorium by deliberating extending a working space for the actors right into the middle of the auditorium.

By the mid-1670s, Davenant's pragmatic adaptation of Lisle's Tennis Court in Lincoln's Inn Fields inspired the design of the most successful purpose-built theatre in Restoration London. This was Sir Christopher Wren's Theatre Royal in Drury Lane, which was completed for Thomas Killigrew's company in 1674. Wren's new playhouse was not much longer but was significantly wider than the early tennis court theatres. The benches in the pit followed the same gently curving line as the front of the stage, while tiers of front and side boxes provided elegant accommodation for wealthy patrons, who were nevertheless close enough to those seated in the pit to be able to talk to them. ${ }^{13}$ Even the more ornate Dorset Garden Theatre, built in 1671 after the death of Sir William Davenant, still followed essentially the same basic disposition of stage and auditorium, albeit on a larger scale, that was established at Lincoln's Inn Fields. ${ }^{14}$ The enduring success of Davenant's original tennis court adaptation was underscored yet again in 1695 when the leading actors at Drury Lane rebelled against their manager, Christopher Rich. The building they chose for their actors' company was Lisle's Tennis Court, Lincoln's Inn Fields, hastily reconverted from tennis court to playhouse, using Davenant's tried and tested conversion scheme. It was to provide them with a secure base until 1705, when they moved to Vanbrugh's new playhouse, the Queen's Theatre in the Haymarket.

\section{Note on the Texts}

The texts of the plays by Dryden, Wycherley and Congreve correspond as far as possible to the first editions. I have retained the original spelling and punctuation of the first editions, though a number of silent editorial changes have been made. Obvious typographical errors have been corrected on the basis of later editions; the modern spelling of the letter ' $\mathrm{s}$ ' has been used throughout; all 
characters' names have been fully spelled out, as have abbreviations in stage directions. All stage directions have been placed between square brackets. Conventions of punctuation and syntax within the brackets have been silently standardised. I have made no attempt to list variant readings in later editions in footnotes. Generally, footnotes have been kept to a minimum so that the text may be read without constant editorial interruption.

The same general editorial principles have been applied to the translations of plays by Racine and Molière. However, these texts have required far greater editorial intervention. In the case of Racine, there were a number of adaptations of his plays in the late seventeenth century, but no accurate translations. (John Crowne published an adaptation of Andromache in 1675 and Ambrose Phillips published his version of the same play called The Distrest Mother, in 1712. Edmund Smith's Phædra and Hippolytus, published in 1707, drew extensively on Racine's Phèdre. $)^{15}$ The translation of Phèdre chosen for this volume is the first listed in the catalogue of the British Library. It was published anonymously in 1776. Although in many respects it offers a lively and spirited version of the original, the translator has omitted and occasionally mistranslated a number of key passages. I have supplied my own versions of the missing or incorrect sections, some of which are based loosely on a nineteenthcentury version of the play published by Robert Bruce Boswell in 1890; I have indicated in the footnotes where this happens.

The translation of Molière's The Miser is by John Ozell, published in 1732. This is an updated and corrected version of a translation Ozell first published in 1714. (Prior to this date, Shadwell had published an adaptation of The Miser in 1672; Fielding was to publish a further adaptation of The Miser in 1733.) A further translation of The Miser was also published in 1732 by Martin Clare, in the first volume of a set entitled Select Comedies of M. de Molière. Generally, Ozell's translation is a superior rendering of Molière's text. However, a few passages are translated more accurately by Clare; where this happens, they have been incorporated in this volume and Ozell's version is given in a footnote. (Clare's version of the play was subsequently published by Baker and Miller in the second volume of their 1739 edition of The Works of Molière.)

An adaptation of Tartuffe, called Tartuffe, or the French Puritan, was published by the actor Matthew Medbourne in 1670. There were further extensive borrowings from Tartuffe by John Crowne in his play The English Friar in 1690 and by Colley Cibber in his play The 
Nonjuror in 1717. The first full translation of Molière's Tartuffe was undertaken by Martin Clare. It was first published in 1732 as an individual volume and in the fifth volume of Select Comedies of M. de Molière. Subsequently it was used by Baker and Miller (with a few corrections and alterations) in the fifth volume of their 1739 edition of Molière's plays, entitled The Works of Molière (10 vols). The version used for this volume is from the 1739 edition. It is usually ascribed to Baker and Miller, but as the greater part is by Martin Clare, it seems only just that he should be given credit for it. Neither edition includes a translation of Molière's Preface and his three petitions addressed to the king. The translation of these items is taken from Henri van Laun's edition, The Dramatic Works of Molière, vol. 4, published in Edinburgh in 1876.

The editions of the plays consulted may be found at the following locations in the British Library:

Text

British Library

John Dryden, All for Love

First edition (London: Henry Herringman, 1678)

Second edition (London: Henry Herringman, 1692)

[644.g.68]

[11774.g.19]

William Wycherley, The Country Wife

First edition (London: Thomas Dring, 1675)

Second edition (London: Thomas Dring, 1683)

Third edition (London: Thomas Dring, 1688)

[C.34.1.26]

[11778.g.36]

[644.i.81]

William Congreve, Love for Love

First edition (London: Jacob Tonson, 1695)

Second edition (London: Jacob Tonson, 1695)

[Ashley 2913]

[841.c.20]

Third edition (London: Jacob Tonson, 1697)

[11783.ff.32]

Jean Racine, Phedra, unknown translator

(London: T. Bell, 1776)

[11735.e.36]

The Dramatic Works of Jean Racine, a metrical English version by Robert Bruce Boswell, 2 vols

(London: George Bell \& Sons, 1889-90)

[2504.k.10]

Molière, The Miser, trans. John Ozell

(London: B. Lintot, 1732)

[164.g.62]

Select Comedies of M. de Molière, 8 vols, trans. Martin Clare

(London: John Watts, 1732)

[241.1.28-35]

Tartuffe, trans. Martin Clare

(London: John Watts, 1732)

[11736.aa.33.(1)]

The Works of Molière, 10 vols, trans.

$\mathrm{H}$. Baker and J. Miller 
(London: John Watts, 1739)

The Dramatic Works of Molière, 6 vols, trans. Henri van Laun

(Edinburgh: William Paterson, 1876)

A number of modern scholarly editions of the plays by Dryden, Wycherley and Congreve have been consulted. These include:

The Works of John Dryden, vol. 13, ed. Maximillian E. Novak (Berkeley: University of California Press, 1984).

The Plays of William Wycherley, ed. Arthur Friedman (Oxford: Clarendon Press, 1979).

The Complete Plays of William Congreve, ed. Herbert Davis (Chicago and London: University of Chicago Press, 1967).

A number of modern translations of Racine and Molière are in print, but at present there are no scholarly editions of these plays in translation.

\section{Notes to the Introduction}

1. Pierre Corneille, Writings on the Theatre, ed. H. T. Barnwell (Oxford: Blackwell, 1965) p. 203.

2. This process was convincingly illustrated in Roberto Rossellini's film The Rise to Power of Louis XIV (1967).

3. John Charlton, The Banqueting House in Whitehall (HMSO, 1964) p. 11.

4. Quoted from D. Thomas (ed.), Theatre in Europe: A Documentary History. Restoration and Georgian England, 1660-1788 (Cambridge: Cambridge University Press, 1989) pp. 11-12.

5. See G. Mongrédien, Daily Life in the French Theatre at the Time of Molière (London: George Allen \& Unwin, 1969) pp. 110-11.

6. See Peter D. Arnott, An Introduction to the French Theatre (London: Macmillan, 1977) pp. 5-16.

7. For a conjectural reconstruction of the interior, see Richard Leacroft and Helen Leacroft, Theatre and Playhouse (London: Methuen, 1984) p. 50.

8. See ibid., p. 50.

9. See Donald C. Mullin, The Development of the Playhouse (Berkeley and Los Angeles: University of California Press, 1970) p. 51.

10. Illustrated in Leacroft and Leacroft, Theatre and Playhouse, p. 69.

11. For a more detailed account of Elizabethan playhouses, see Mullin, The Development of the Playhouse, pp. 32-9.

12. See Thomas, Theatre in Europe, pp. 55-7.

13. For a detailed account of the design of Wren's Theatre Royal, Drury Lane, see ibid., pp. 69-72.

14. For a conjectural reconstruction of Dorset Garden by Edward Langhans, see Mullin, The Development of the Playhouse, p. 69.

15. See Katherine Wheatley, Racine and English Classicism (Austin: University of Texas Press, 1956). 